\title{
HEALTH AND LAW
}

\section{Criminal liability for medical negligence: a drastic change?}

\section{R HARIHARAN NAIR}

(Retired Kerala High CourtJ udge), Chairman, Institutional Review Committee, Sree Chitra Tirunal Institute for Medical Science and Technology, Thiruvananthapuram 695011, Kerala, India. email: justicemr@sancharnet.in

The Supreme Court declared on August 4, 2004, in Dr Suresh Gupta’s Criminal Appeal [Appeal (crl.) 778 of 2004] that to sustain a prosecution for the offence under S. 304A of the Indian Penal Code (IPC), and to fix criminal liability on a doctor or surgeon, the standard of negligence required to be proved should be so high that it can be described as 'gross negligence' or 'recklessness', not merely lack of necessary care. On those premises it quashed the criminal proceedings against Dr Gupta before they reached trial in the Magistrate's Court.

Until this judgment came out, a precedent was set by the decision of the Supreme Court dated February 4, 2004, in Mohanan v. Prabha G Nair and another (2004) CPJ 21(SC). In this case, a woman in the seventh month of pregnancy underwent medical intervention and delivered a dead child on the next day. She passed away three days later, while under medical care. The husband alleged in his police complaint that though he repeatedly asked for permission to remove his wife to a medical college hospital, the doctor advised against the shift saying that the patient had no serious problem and that everything would turn out all right. Subsequent events obviously proved otherwise.

Based on the opinion of the radiologist and the doctor who conducted the autopsy, the Criminal Court took cognisance of the offence punishable under S.304A of the IPC. The doctor petitioned to quash the proceedings invoking S. 482 of the Criminal Procedure Code, on the ground that there was no prima facie case. The concerned High Court held that the mere fact that a patient dies in a hospital does not lead to the presumption that the death occurred due to the doctor's negligence. To hold a doctor criminally responsible for a patient's death, it must be established that there was negligence or incompetence on the doctor's part, which went beyond civil liability. Criminal liability would arise only if the doctor did something in disregard to the patient's life and safety.

The Supreme Court, however, set aside the said High Court decision holding that the doctor's negligence could be ascertained only by scanning all material and expert evidence that might be adduced during the trial. The High
Court was held not justified in quashing the complaint at the threshold invoking the special power under S. 482 of the Criminal Procedure Code as that would do away with a full-fledged criminal trial necessary for fixing criminal liability.

\section{Relevant legal provisions}

According to S. 304A of the IPC, whoever causes the death of any person by a rash or negligent act not amounting to culpable homicide shall be punished by imprisonment for up to two years, or by fine, or both.

According to S. 80 of the IPC, "nothing is an offence which is done by accident or misfortune, and without any criminal intention or knowledge in the doing of a lawful act, in a lawful manner, by lawful means and with proper care and caution.' In other words, if a person commits an act by accident or misfortune without a criminal intention, using lawful means and with proper care and caution, his action cannot be labelled a criminal offence.

Again, S. 88 of the IPC provides that nothing which is not intended to cause death, is an offence by reason of any harm which it may cause, or be intended by the doer to cause, or be known by the doer to be likely to cause, to any person for whose benefit it is done in good faith, and who has given a consent, whether express or implied, to suffer that harm, or to take the risk of that harm. In other words, an act, not intended to cause death, and done in good faith and with the consent of the other party, cannot be labelled an offence even if it leads to the other party's death or disability. It may also be mentioned here that the word 'good faith' used here has a special meaning. It means an act done wih due care and attention.

Let us analyse the recent Supreme Court decision in the light of the legal positions stated above.

On April 18, 1994, Dr Suresh Gupta, a plastic surgeon, operated on his patient for removing a nasal deformity. Allegedly, he made an incorrect incision as a result of which blood seeped into the patient's respiratory passage leading to his immediate collapse and death. A case was filed against the doctor under S. 304A of the IPC. The 
anaesthetist who assisted Dr Gupta in the operation was also made co-accused; but he died while the trial was pending. The criminal proceedings therefore continued against Dr Gupta alone.

Rejecting Dr Gupta's plea for discharge without trial, the magistrate noted that according to the post-mortem report, the cause of death was 'blockage of respiratory passage by aspirated blood consequent upon surgically incised margin of nasal septum'; that the medical experts constituting the Special Medical Board set up for the investigation had opined that the blockage and aspiration of blood from the wound were not likely to arise if a cuffed endotracheal tube of proper size had been introduced before the operation and kept intact, and that the negligence in not taking this precaution justified further trial proceedings.

The Supreme Court did not agree to this. It has now held that to fix criminal liability on a doctor or surgeon, the standard of negligence required to be proved should be so high that it can be described as gross negligence or recklessness and not merely lack of necessary care, attention and skill. Every careless act of a medical person cannot be termed 'criminal'. It can be termed 'criminal' only when doctors exhibit gross lack of competence or inaction, and wanton indifference to their patients' safety, as a result of gross ignorance or gross negligence. When a patient's death results merely from an error of judgment or an accident, no criminal liability should be attached to it. Mere inadvertence or some degree of want of adequate care and caution might create civil liability; but not criminal liability. It was held that but for this approach, the hazards in the medical profession which include civil liability would also unreasonably extend to criminal liability, and doctors would then be at the risk of landing up in prison, a result that would shake the mutual confidence between doctor and patient.
Based on these facts, the Supreme Court held that though the patient was a young man with no history of any heart ailment, the operation to be performed for nasal deformity was not so complicated or serious; and that the alleged lapse, i.e. the failure to introduce a cuffed endotracheal tube of proper size to prevent aspiration of blood from the wound in the respiratory passage, could not be described as a reckless or grossly negligent act as to make him criminally liable. Holding that such evidence was wanting, the doctor was acquitted without trial.

Were these findings not similar to those held by the High Court concerned, though in different words in Mohanan's case, but found unsustainable by the Supreme Court then? If the quashing of the charge with the observation that the doctor's negligence could be ascertained only by scanning the material and expert evidence that might be adduced during a prospective trial was not in order in Mohanan's case, how could the reason given for quashing charges in Dr Suresh Gupta's case be correct?

It appears that if the decision in Mohanan's case had been followed by the later Bench that decided Dr Suresh Gupta's case, the ultimate decision might have been different. Probably the earlier decision was not cited before the new Bench.

The impact of the judgment, though significant, may be short lived. The reason is that according to press reports, a Bench consisting of Justice Arijit Pasayat and CK Thakker, on or about September 9, 2004, has referred the question of medical negligence for determination by a larger Bench of the Supreme Court observing that the words 'gross, reckless, competence, indifference' etc. did not occur anywhere in the definition of 'negligence' under S. 304A of the IPC, and hence, they could not agree with the judgment delivered in the case of Dr Suresh Gupta. Thus the matter will come up for review before a larger bench of the Supreme Court any time now. 